\title{
Evaluation of accuracy of transvaginal ultrasound in lower uterine segment caesarean scar integrity and histomorphometric analysis of scar tissue: a prospective study
}

\author{
Simmi Salim¹, Biju Parameswaran ${ }^{2 *}$, Deepthi Balakrishnan ${ }^{1}$
}

\author{
${ }^{1}$ Department of Obstetrics and Gynaecology, SUT Academy of Medical Sciences, Vattapara, Trivandrum, Kerala, \\ India \\ ${ }^{2}$ Department of Obstetrics and Gynaecology, SBM Hospital, Karunagappally, Kerala, India
}

Received: 16 October 2020

Accepted: 23 October 2020

\section{*Correspondence:}

Dr. Biju Parameswaran,

E-mail: sarathgrey@gmail.com

Copyright: () the author(s), publisher and licensee Medip Academy. This is an open-access article distributed under the terms of the Creative Commons Attribution Non-Commercial License, which permits unrestricted non-commercial use, distribution, and reproduction in any medium, provided the original work is properly cited.

\section{ABSTRACT}

Background: Caesarean section is the most common method of delivery in the present conditions. The present study conducted to evaluate the accuracy of transvaginal ultrasound in lower uterine segment caesarean scar integrity and histomorphometric analysis of scar tissue.

Methods: The study was conducted in the department of OBG, SUT academy of medical sciences, Vattapara, Trivandrum, Kerala. Based on the inclusion and exclusion criteria a total of 144 patients were included in the study. All patients explained study procedure and informed consent was obtained. They were subjected to transvaginal ultrasound examination after that small piece of scar tissue was taken and used for histomorphic analysis. The data was analysed by SPSS (16.0) version used.

Results: In group-I $31.11 \%$ showed 40 and above fibrosis and group-II $85.0 \%$ had fibrosis 40 and above. 8 in group-I showed $0-19 \%$ of fibrosis and 17 in group-II. $0-19 \%$ whereas vicryl had a range of $0-40 \%$ and above and the rate of fibrosis compared to transvaginal sonography not showed significant difference.

Conclusions: Histomorphological analysis of scar tissue gave accurate results and it was similar to transvaginal ultrasonography results.

Keywords: Fibrosis, Transvaginal sonography, Histomorphology, Scar, Nucleus, Tissue

\section{INTRODUCTION}

Lower segment caesarean section (LSCS) one of the common methods of delivery. There is a formation caesarean scar. The uterine scar heals by regeneration of the muscular fibres and not by the development of scar tissue. They may be visible as a vertical furrow in the external and internal surface of the anterior uterine wall. $^{1,2}$ In the other hand Schwartz et al study explained that the healing was mainly by fibroblast proliferation, they studied that uterine incision site some days after the caesarean section and observed that as the scar shrinks, connective tissue proliferation become less obvious. If the cut surface of uterus is closely apposed, the proliferation of connective tissue is minimal and the normal relation of smooth muscle to connective tissue gradually is re-established. Risk of uterine rupture would be increased if the hysterotomy scar did not have sufficient time to heal. ${ }^{3}$ Studies of uterine scar healing using magnetic resonance imaging suggest that complete uterine involution and restoration of anatomy require at least 6 months. It was observed that scar formation may be affected by lesser blood supply, formation of haematoma, improper surgical procedure, infection and anemia. ${ }^{4}$ Poeidivin et al recommends that technique for repair of LSCS incision. Identify the wound edges soon 
after the placenta is removed and control the bleeding with non-crushing instruments and suture it by uninterrupted chromic catgut. The study proved that incidence of scar rupture following lower segment section is $1.4 \%$ after classical operation. ${ }^{5}$ Scar thickness also gives the idea about rate of fibrosis. ${ }^{6}$ Various studies showed that scar thickness less than 3 indicate the slow fibrosis process and above 3 is fast fibrosis process. Increase the scar thickness reduces the complication during next LSCS. $^{7}$ This was proven in various studies. This was further conformed by histopathological analysis of scar tissue. It was observed that appearance of more nucleuses in scar histology indicate the fast healing. ${ }^{8}$ The thickness of scar also increased. Scar thickness can be measured with use of transvaginal sonography. With this background the present study aimed to evaluate the accuracy of transvaginal ultrasound in lower uterine segment caesarean scar integrity and histomorphometric analysis of scar tissue.

\section{METHODS}

\section{Study settings}

The prospective study was done in the department of obstetrics and gynaecology, SUT academy of medical sciences, Vattapara, Trivandrum, Kerala. The study was done during the period of August 2012 to September 2014.

\section{Inclusion criteria}

Criteria for inclusion in current study were; past LSCS surgery and women with previous LSCS and antenatal.

\section{Exclusion criteria}

Criteria for inclusion from current study were; undergone more than 2 times LSCS, placental abnormalities, multiple pregnancy and recent endometrial surgery.

\section{Procedure}

The study was started after obtaining the permission from institutional human ethics committee (IHEC). Convenient sampling technique used for sample collection. Total 144 patients were included in the study on the basis of inclusion and exclusion criteria. All patients were explained study procedure and informed consent was obtained. Out 144 only 85 patients were subjected to histomorphic analysis and 59 were rejected because 42 under gone elective surgery and 17 emergency delivery. Small piece of scar was collected from 85 patients and used for micromorphological analysis.

\section{Statistical analysis}

Statistical package for social sciences (SPSS 16.0) version used for analysis. The data was expressed in number and percentage.

\section{RESULTS}

The study included total 144 patients. Histomorphological test was done on 85 patients. The selected patients were divided into two groups based on the thickness of scar. Patients with less or equal to $3 \mathrm{~mm}$ were included in group-I and above $3 \mathrm{~mm}$ were included in group-II. 11 patients in group-I showed 10-19\% fibrosis but 1 patient showed same percentage of fibrosis in group-II. 34 patients in group-II showed $40 \%$ and above fibrosis and in group-I, 13 showed same percentage of fibrosis. Patients underwent primary section outside in those 9 patients in group-I and 17 in group-II showed $40 \%$ or above fibrosis. In group-II none of them showed 10-19 and 30-39\% of fibrosis. 8 in group-I and 1 in group-II showed $0-9 \%$ of fibrosis (Table 2). Vicryl chromic catgut suture material used in the study. Maximum patients in group-I and II used vicryl suture material compared chromic catgut. 5 in group-I and 17 in group-II had $40 \%$ and above fibrosis in these patients vicryl used. Chronic catgut was used only in group-I have $0-9 \%(\mathrm{~N}=2)$ and $10-19 \%(\mathrm{~N}=1)$ fibrosis (Table 3). More number of nucleus, muscle tissue and collagen was observed in group-II scar tissue compare to group-I. Presence of more cells, tissue and collagen indicates the fibrosis processes. Group-II showed faster fibrosis process than group-I (Figure 1).

Table 1: Comparison of transvaginal sonography with histomorphometric measurement of rate of fibrosis.

\begin{tabular}{|lllll|}
\hline $\begin{array}{l}\text { Fibrosis } \\
(\%)\end{array}$ & \multicolumn{2}{c|}{ Group-I $(\geq 3 \mathrm{~mm})$} & \multicolumn{2}{c|}{ Group-II $(<3 \mathrm{~mm})$} \\
\hline $\mathbf{0 - 9}$ & $\mathbf{N}$ & $\mathbf{( \% )}$ & $\mathbf{N}$ & $\mathbf{( \% )}$ \\
\hline $\mathbf{1 0 - 1 9}$ & 11 & 22.22 & 1 & 2.50 \\
\hline $\mathbf{2 0 - 2 9}$ & 8 & 17.74 & 1 & 2.50 \\
\hline $\mathbf{3 0 - 3 9}$ & 3 & 6.67 & 3 & 7.50 \\
\hline $\begin{array}{l}\mathbf{4 0} \text { and } \\
\text { above }\end{array}$ & 13 & 28.89 & 34 & 2.50 \\
\hline
\end{tabular}

Table 2: Correlation of transvaginal sonography with rate of fibrosis in patients who had their primary section done outside.

\begin{tabular}{|lllll|}
\hline $\begin{array}{l}\text { Fibrosis } \\
(\%)\end{array}$ & \multicolumn{2}{c|}{ Group-I $(\geq 3 \mathrm{~mm})$} & \multicolumn{2}{c|}{ Group-II (<3mm) } \\
\hline $\mathbf{0 - 9}$ & $N$ & $(\%)$ & $N$ & $(\%)$ \\
\hline $\mathbf{1 0 - 1 9}$ & 8 & 25.81 & 1 & 4.76 \\
\hline $\mathbf{2 0 - 2 9}$ & 5 & 25.81 & 0 & 0.00 \\
\hline $\mathbf{3 0 - 3 9}$ & 1 & 3.23 & 0 & 0.00 \\
\hline $\begin{array}{l}\mathbf{4 0} \text { and } \\
\text { above }\end{array}$ & 9 & 29.03 & 17 & 80.95 \\
\hline
\end{tabular}

\section{DISCUSSION}

Histomorphic analysis plays major role in the diagnosis of various diseases. It gives confirmed results with maximum accuracy. But doing this may not be possible in all the patients. This is the major limitation of 
histomorphic studies. It can be overcome with use of noninvasive procedures like X-ray, ultrasound and MRI. All pathological changes cannot be noticed in X-ray and some patients may not afford MRI. Transvaginal ultrasound is one of the diagnostic tool used commonly to detect varies pathological changes in the body. The present study 59 patients were subjected to transvaginal ultrasound to detect the rate of fibrosis. When trans vaginal sonography measurement was compared with measurement of rate of fibrosis it was observed that the highest rate of fibrosis was with group-II that is less than $3 \mathrm{~mm}$.

Table 3: Correlation of transvaginal sonography with rate of fibrosis and suture material used in primary section in SUTMC.

\begin{tabular}{|c|c|c|c|c|}
\hline \multirow{3}{*}{$\begin{array}{l}\text { Fibrosis } \\
(\%)\end{array}$} & \multicolumn{4}{|c|}{ SUTMC (n=21) } \\
\hline & \multicolumn{2}{|c|}{ Group-I ( $\geq 3 \mathrm{~mm})$} & \multicolumn{2}{|c|}{ Group-II (<3mm) } \\
\hline & Number & Rate & Number & Rate \\
\hline \multirow[b]{2}{*}{$0-9$} & 2 & Vicryl & \multirow[b]{2}{*}{1} & \multirow[b]{2}{*}{ Vicryl } \\
\hline & 2 & $\begin{array}{l}\text { Chromic } \\
\text { catgut }\end{array}$ & & \\
\hline \multirow[b]{2}{*}{ 10-19 } & 2 & Vicryl & \multirow[b]{2}{*}{1} & \multirow[b]{2}{*}{ Vicryl } \\
\hline & 1 & $\begin{array}{l}\text { Chromic } \\
\text { catgut }\end{array}$ & & \\
\hline $20-29$ & 4 & Vicryl & 0 & - \\
\hline 30-39 & 1 & Vicryl & 1 & Vicryl \\
\hline $\begin{array}{l}40 \text { and } \\
\text { above }\end{array}$ & 5 & Vicryl & 17 & Vicryl \\
\hline
\end{tabular}

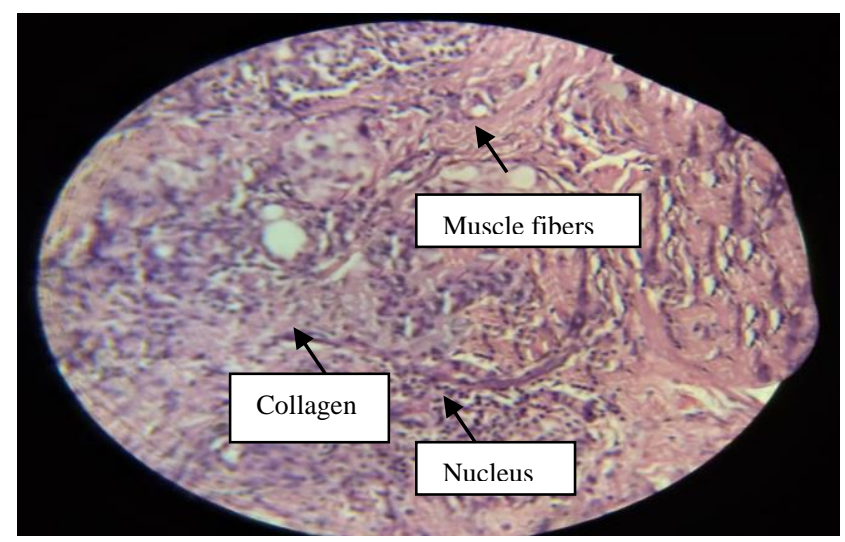

Figure 1: Histomorphic analysis of scar tissue.

Meajia et al measured fibrosis in a sample obtained from the uterine scar region finding the higher rate of fibrosis $(35.70 \%)$ for the group with one previous caesarean section. He concluded that uterine scar shows no clear difference after one, two or more caesarean section. ${ }^{9}$ Ejub et al study conclude that transvaginal ultrasound evaluation of scar tissue homogeneity depends on the rate of fibrosis. It was more confined with the histomorphological reports. It was observed that scar above $3.5 \mathrm{~mm}$ showed slow fibrosis compared less than $3.5 \mathrm{~mm}$. In the present study also observed similar results. ${ }^{10}$ Nilanchali et al study concluded that increased scar thickness is better for successful vaginal birth. Scar thickness is depends on the process of fibrosis. It was observed that scar less than $3 \mathrm{~mm}$ showed lesser percentage of fibrosis and it is further confirmed by histology study. ${ }^{11}$ Cailin et al explained radiological examinations are partially helpful for the diagnosis of fibrosis but a definitive diagnosis is made by histopathological examination. He concluded that scan reports and sonography observations are similar. ${ }^{12}$ In the present study showed $98.9 \%$ correlation between histopathology and transvaginal sonography results. The study results given scope to use the transvaginal ultrasound for evaluation of rate fibrosis process in scar tissue of caesarean section.

\section{Limitations}

The limitations of the current study were; less sample size, no use of any special staining methods, some of the patients did not appear for the last follow up.

\section{CONCLUSION}

Transvaginal sonography gives the better results in the measurement of rate of fibrosis. These results were similar to histology reports. This study results is concluded that transvaginal sonography is non-invasive procedure can have more patient compliance compared to histomorphological procedure.

Funding: No funding sources Conflict of interest: None declared

Ethical approval: The study was approved by the Institutional Ethics Committee

\section{REFERENCES}

1. Fabres C, Aviles G, Jara DL, Escalone J. The caesarean delivery scar pouch: clinical implication and diagnostic correlation between transvaginal sonography and hysteroscopy. J Ultrasound Med. 2003;25(9):1095-01.

2. Cheng $\mathrm{Y}$. Uterine dehiscence $\mathrm{n}$ term patients with one previous less and fibrosis in uterine scar. Ultrasound Med. 1996;8:120-4.

3. Fabres C, Aviles G, Jara DL, Escalone J, Munoz JF. Comparative study of lower uterine segment afet caesarean section using ultrasound and magnetic resonance tomography. Eur J Obstet Gynecol Reprod Biol. 1992;45(3):185-6.

4. Robert LJ, Beardsworth SA, Trew G. Labour following caesarean section current practice in United Kingdom. Br J Obstet Gynecol. 1994;101: 153-5.

5. Arulkumaran S, Ingemarsson G, Kitchener HC, Ratnam SS. Uterine activity during spontaneous labour after previous lower segment caesarian section. Br J Obstet Gynecol. 1989;196:933-93.

6. Asakura H, Nakae A, Ishikawa P, Suzuki S. Prediction of uterine dehiscence by measuring lower 
uterine segment thickness prior to the onset of labour evaluation by transvaginal ultrasound. J Nippon Med Sci. 2000;67(5):352-6.

7. Bcall ME, Clarks GS. Vaginal delivery after CS in women with unknown types of uterine scar. J Reprod Med.1984;29:31-2.

8. Fukunda M, Shimizu, Ihara Y, Fukunda K, Natsuyama F. Ultrasound examination of caesarian scar during pregnancy. Arch Gynecol Obstet. 1991; 248:129-38.

9. Maejia R, Escalone A, Cabello A, Videe S. Post caesarian uterine scar. Rev Chil Osctet Gynecol. 1989;54(5):307-9.

10. Ejub B, Vesna BC, Hadzo K, Admir R. Ultrasound evaluation of uterine scar after cesarean section. Acta Inform Med. 2012;20(3):149-53.

11. Nilanchali S, Reva T, Mala YM, Rashmi D. Scar thickness measurement by transvaginal sonography in late second trimester and third trimester in pregnant patents with previous cesarean section: dose sequential change in scar thickness with gestational age correlate with mode of delivery. J Ultrasound. 2015;18(2):173-8.

12. Cailin W, Xin C, Zhixiong M, Juan Z, Liangzi W. A preliminary study of uterine scar tissue following caesarean section. J Perinat Med. 2018;46(4):379-86.

Cite this article as: Salim S, Parameswaran B, Balakrishnan D. Evaluation of accuracy of transvaginal ultrasound in lower uterine segment caesarean scar integrity and histomorphometric analysis of scar tissue: a prospective study. Int $\mathbf{J}$ Reprod Contracept Obstet Gynecol 2020;9:4874-7. 